\title{
Preface: The Space of Restoration
}

In recent years a number of prominent scholars have embarked upon a sentimental journey to look at themselves and their early work, in order to determine, I suppose, who they were at the time of the writing, what they might have been, and how that earlier self is related to the older observer. This form of activity is particularly overdetermined in disciplines like anthropology, which have become prepossessed by a concern for the reflexivity of the ethnographer's position. In fact, reflexive anthropology, for want of a better name, has generated a new genre of writing, if not a small cottage industry, that seeks to account for the specular relationships between the act of observing, where one stands, and the subject that is being viewed. The field's current crisis results from an acknowledged uncertainty concerning who is gazing at whom.

Although the reflexive mode is employed frequently to mark the place of a new preface to a book or study published before, and even seems to have been invented for such a purpose, it is not my intention to meditate long, or at all, on the relationship between who and what I was twenty years ago when I brought out Toward Restoration (University of California Press, 1970) and how the intervening years have inevitably either confirmed or disconfirmed my central interpretations and arguments. A variation of this approach 
has been the more familiar attempt to survey the literature on the subject in question-in this instance, the Meiji Restoration-published over the past twenty years in order to demonstrate that "new" research has not seriously jarred the book's principal theses. Since I've never been persuaded by the positivist piety that unearthing new documentary material will invariably affect the nature of interpretation (indeed, it would be difficult to find an interpretation dismantled by new data), such a survey would be an unproductive act.

Toward Restoration was simply a reading of some of the scholarship concerning the Meiji Restoration and the central texts produced by late Tokugawa activists. At the time of writing the book, it was my intention to situate a particular historical conjuncture of the midnineteenth century, since my thinking was itself mediated by the history we were living through in the decade of the 1960s. The book frequently aspired to the status of an allegory and still discloses traces of this purpose in its conclusion. Nevertheless, I am still interested more in reading for what Walter Benjamin calls "construction" than research for historical reconstruction, which involves historians not in a hermeneutics of empathy but in a performative that imagines history for the political effects they might choose to elicit from it. Since the publication of Toward Restoration, however, I have been supplied with new and different means to express the strategic choice of reading over reconstructing and representing.

Recognizing that the book was more about reading, as such, than about anything else raises the question of what this reading yielded about the production of texts in the late Tokagawa period. The production of so many texts calling for action against the foreigners or the bakufu and circulating plans for some vague restorationist scheme abundantly signifies that something needed to be done about the received arrangement of political control and its evident incapacity to stem either domestic disorder or the threat of foreign colonization. My reading disclosed a vast terrain appearing in the late Tokugawa period on which it was possible to map the constitution of a public and "social space" contiguous to pre- 
vailing structures." In fact, my "reading" situated the late Tokugawa period as a terrain crisscrossed by conflicts and antagonisms that had to be resolved if the Japanese polity was to survive. The discourse of loyalist-samurai was merely one among many comparable textual interventions in late Tokugawa Japan (it was also something more than a textual moment, since many of these activists gave up their lives before the Restoration) that claimed the rights both to occupy a "space of representation" and to construct the "representation of space." 2 The former concerned the "theoretical status" of the notion of space (perception, conception, representation); the latter related to forms of action (construction, production, projection).

I would like to elaborate on this kind of reading of Toward Restoration, thereby explaining loyalism only partially as a moment leading toward the Restoration (although the book is often marked by this kind of historiographical closure). I would like to show that the sonn $\overline{0} j \bar{o} i$ movement to restore the emperor and expel the foreigners, which derived from the theories of the Mito School, was but one of a number of discourses occupying the same terrain and calling for a new kind of social and political space. But first, I must note that in the years after my book was published, theory and cultural studies underwent a revolution, which now seems to be sliding into reaction and renunciation. Moreover, the years have not been kind to the study of the Meiji Restoration. Not only has the production of monographs slowed down, suggesting perhaps that scholars-especially Japanese scholars-are according the event less importance. But the Restoration has even become trivialized for mass consumption, as in the recent volume of cartoons illustrated by one of the really important historians of the subject, Naramoto

"The idea of "social space" has been brilliantly conceptualized and articulated in Kristin Ross, The Emergence of Social Space: Rimbaud and the Paris Commune (Minneapolis: University of Minnesota Press, 1988). I have relied heavily on Ross's formulations concerning social space, which have helped me enormously to clarify my own rather inchoate thinking. The book is a model for the historical poetics people have been writing about "theoretically" but rarely get around to doing.

${ }^{2}$ Henri Lefebvre, Le droit à la ville (Paris: Editions Anthropos, 1972), 169. 
Tatsuya. ${ }^{3}$ (Naramoto undoubtedly made more money from this comic book than from all of the books he wrote on the Meiji Restoration and the late Tokugawa period when he was still a hard-line Marxist scholar.)

If Toward Restoration was not driven by theory, it still sought to show how we might read the cultural text of late Tokugawa Japan and use it to grasp the immensely complex political spectacle taking place. I intended my study to redress the excessive privileging of institutional, economic, and biographical elements that most historians of the subject had endowed with explanatory force. As a result, thought as such or what I have now chosen to call the cultural text was seen as a secondary-superstructural-activity or, worse, simply marginalized. Instead, I chose to grasp it as a performative empowered with constitutive force, especially of all those political identities that ultimately authorized people to act and to sacrifice themselves for a vague goal they never lived to see. One of the ironies of historians' concentration on what Foucault once, too hastily, called the "nondiscursive" realm is that it overlooks precisely the efforts of loyalist-activists to eliminate the disastrously consequential sundering of thought and action they perceived in the conduct of affairs and its subsequent service in the interests of a hegemonic order.

The principal leitmotiv informing loyalist thought, as well as that of other discourses, was the reinscription of thought in practice and practice in thought; their alignment became a way of envisaging a new conception of public space and a new social imaginary. In the overheated environment of late Tokugawa politics, sonn $\bar{o} j \bar{o} i$ activists contested an arrangement fostered by the "interest" of the Tokugawa bakufu, which drew its authority by displacing the division between thought and practice to a "natural" differentiation between head and hand, mental and manual labor. Activists sought to dismantle the Tokugawa bakufu by employing a strategy of spatial displacement, not by a progressive movement leading to revolutionary upheaval that could later be emplotted for

${ }^{3}$ Naramoto Tatsuya, Bakumatte nan darō (Tokyo: PHP Kenkyujo, 1990). I want to thank George Wilson for alerting me to this text and making it available. 
a linear story-line demanding narrative closure. The Restoration was a revolutionary moment to eliminate the spectacle of what I refer to as several co-existing "restorations" that claimed they could resolve all of the uncertainties of the received polity and yet stand as an adequate substitute for an unenvisaged whole. Only when the Meiji Restoration removed the possibility of plural articulations that had stamped the late Tokugawa "experience" and the primacy of space did it become an event inaugurating in time Japan's narrative of modernization.

What has changed, then, is not so much my interpretation but rather the way I have come to talk about the interpretative act itself. During the two decades that have passed since the publication of Toward Restoration, the human sciences (by which I mean the "softer" social sciences) have been inundated and transformed by new critical strategies that have either privileged text over context, thereby making the act of interpretation into a reading regime, or problematized their relationship, thereby preventing the reduction of the former to the latter, since the construction of both derives from the same materials. While I have tried elsewhere ${ }^{4}$ to describe the importance of this critical intervention for history, it is important to suggest here that the new critical strategies have played little or no role in penetrating the discipline of history, which seems bent on becoming the bastion of reaction and resistance to the promises of theory. But then historians here and abroad have invariably read theory as a code for Marxism.

Even historical critiques that have tried sympathetically to familiarize themselves with the newer critical practices-as against the mock but unknowing outrage expressed by historians like Lawrence Stone, speaking in the institutional voice of custodianshave too often sought to resist new theory by arguing that "language is not life."5 Yet only language makes possible a statement that announces the thundering truth that something lies outside

${ }^{4}$ H. D. Harootunian, Things Seen and Unseen (Chicago: University of Chicago Press, 1988).

'The quote is not from Stone but from Bryan D. Palmer, Descent into Discourse (Philadelphia: Temple University Press, 1990), xiv. 
words, even though words must be used to describe this form of life. A veritable army of resisters have unfailingly and unnecessarily reminded us about this division and what Perry Anderson called the "exhorbitation of language," exhorting us (and themselves, I suppose) that life exists elsewhere, outside or safely apart from language and discourse. But such a view betrays both a misunderstanding of certain poststructural claims and a nervous uneasiness about the future of disciplines like historical studies. Even generous critics who attribute some value to semiotics and discourse theory in reading documents often forget that language, while separate from something called life, is not simply a neutral instrument capable of transparent reflection. They also fail to recognize that theories like Barthian semiotics and Derridian deconstruction seek to show that history itself as practiced in the West is the problem, since it is always written. Because historical practice is reading/writing, any effort to use it (or Marxism, as practiced by Michael Ryan) would be unproductive and plainly contradictory to deconstruction's claims. When Barthes pointed out that the referent of historical narrative, which was supposed to reside outside the account as a guarantee of its "reality," was actually produced by language, he was simply forcing us to acknowledge that the real that history is supposed to refer to is only an effect of the actual writing of the narrative. Barthes was thus able to show that the reality of history is in its writing, not in a putative past that we try to reach through its textual traces, the inscriptions of language left behind an event.

This fear-that history cannot lay claim to the authority of an autonomous referent that will guarantee its "reality," except by the very language used to convey the narrative-has panicked historians into denouncing all critical practices that question the ground of determinacy as faddism pandering to student interests, an assault on humanistic values, irrationality, nihilism, insubstantiality, jargon, and so forth. Many new practices are, of course, vulnerable to criticism and should only be embraced with hesitation. Critics like Peter Dews in his Logics of Disintegration have alerted us to the really substantive aporias raised when applying poststructural 
strategies and trimmed down their claims substantially to offer us a set of more reasonable expectations and usable operations.

Believing that there is an outside, out there, some historical critics have dismissed the "primacy" of language or charged practitioners with contracting discursive imperialism (the dreaded disease also known as Foucaultism). Such attacks are usually in defense of a deeper piety which has long insisted, without adequate articulation, that a division exists between materiality and ideality, between life and language, or-in its most recent avatar-between economic, political, and social forces and thought and culture. Moreover, the division tends to assume that "materiality" is really prior to "ideality" and empowers the former to explain the latter. This view is shared by many Marxists and non-Marxists alike and even prompted Michel Foucault once to observe that he saw no appreciable difference between historians and Marxists. What appears to have been put into question here is the historians' cherished conviction that the material, as juxtaposed to the ideal, necessarily supplies the ground of sure referentiality and that ideality (the superstructural) only reflects this guarantee. In this regard, they assume that only things identifiable as material forces can generate and account for change; thought, culture, and literature have no explanatory or constituent causal capabilities. All of these assumptions are pressed into the service of "reconstructing" the past as it supposedly was and foreclosing the humbler alternative of "constructing" an imaginary in the present through the act of reading/writing. But even if the more modest definition of historical practice is rejected, it still must be argued that language, text, and discourse are material productions whose properties we can see, touch, see, and hear-quite physical sensations that, unfortunately, are unavailable to us when we try to reckon with the past as an object of analysis. It is not the past historians seek to reach but its aura.

The initial purpose of Toward Restoration was to provide a textual account of a specific nineteenth discourse (sonnō jōi) - to read the texts of activists who attacked the Tokugawa bakufu because of its incompetence in the face of domestic disorder and foreign danger and to determine how they were constituted and produced in a par- 
ticular historical conjuncture. The loyalist-activists saw no contradiction between producing texts and acting productively, which usually meant committing violence. But even though the loyalistactivists tried to achieve goals that were often contradictory, as differing contexts invariably changed people's minds, their discussion was organized around certain objects, concepts, concerns, and terms to structure a space that was ultimately marked by the figure of restoration.

Yet what I failed to see when I wrote the book is that the constitution of this spatial terrain was not simply the product of loyalist activities. Rather, it was created by several simultaneous discourses representing different social audiences, whose immediate concerns frequently "fused" into what Louis Althusser described as "a ruptural unity." Together, the several discourses signified the overdetermined representation of a vast social and public space; its presence projected a solution that promised relief and assistance from the hardships inflicted by contemporary history, as well as the security and tranquillity to survive in the last, dark days of the Tokugawa bakufu. In this process, the multiple causes or antagonisms agitating the Tokugawa order and the contradictions facing its rulers reappeared with intense regularity in condensed form to shape an image of rupture and fragmented meaning. Mito/ loyalism, nativism (kokugaku), new religions, and the discussion of wealth and power all brought new discursive practices into play. They combined to announce the centrality of difference and even marginality and to constitute new social identities and subjectivities. The emergence of the space of restoration signaled the collapse of a view that had divided political space between ruler and ruled, had legitimated its authority by presupposing a hierarchical cosmic order reflected in precise and determined social relationships (which people involuntarily occupied), and had excluded the possibility of a subject defining itself.

Each of the new discourses, including the loyalist inflection, acknowledged the end of a simple division between ruler (mental labor) and ruled (menial labor), which had authorized a vertical, hierarchical order accountable only to itself - that is, the cosmos- 
and directed by a metaphysics based on the paradigm of nature. As long as such a holistic social imaginary persisted, politics would remain a mere repetition of fixed hierarchical social relationshipsthat is, mere administrative routine. The new discourses "recognized" the need for a space capable of articulating a new conception of the social-in fact, the social itself-and identifying different relationships appropriate to it. But the really important effect of these discourses was the overdetermined effort to annul the contradictions among a growing number of differences. Collectively, they brought to light a plurality of meanings of the "social" and made clear the difficulties in any attempt to fix differences as moments of a stable structure.

I have argued elsewhere that discourses like the Mito/loyalist one spoke to issues that constituted society's business, not other people's business. This meant that discussions of order, security (against both domestic and foreign violence), productivity, relief, and assistance had to conceptualize a "social space," a sanctuary for the safe realization of these goals. One of the recurring ideologemes of the several discourses, including that of the loyalist-activists, was the importance of daily life and the "practical" knowledge and logic of practice it could provide both in constructing new subjectivities and in "mastering" the various "histories" of the folk who constituted its different audiences. ${ }^{6}$ It realigned the political economy and the libidinal economy, the space of representation and the representation of space, demonstrating that the daily lives of ordinary people contained specialized knowledge that had remained marginal to the official discourse and outside the great themes of moral life necessitated by a division between mental and manual labor.

This new space was now occupied by differing voices claiming the right to speak on, participate in, and even act on issues affecting the lives of groups of people about whom official discourse had remained silent by designating them, according to Aizawa Seishisai, simply those who "do not know but must obey." Here, the terms of legitimation shifted from cosmic and natural princi-

${ }^{6}$ Ross, The Emergence of Social Space, 33. 
ples to human agency, performance, and above all else, the necessity of production derived from the practice of the daily life. The development of "new forms of social consciousness," discourses calling for the importance of productivity, imbricated new forces of production and played an equally constituent role in the transformation process. ${ }^{7}$ At the heart of this vast transformation was the effort to resituate the human body, which, in the late Edo culture of play, had been deployed as an instrument of inexhaustible and never-completed pleasure. By positioning daily life and practicality at the forefront of serious consideration, the several discourses were calling attention to the tangible and sensuous-that is, the material-as opposed to the abstract and formal. This particular privileging of the material and bodily derived from the production of practical knowledge that was rooted in the daily lives of the various social constituencies-a knowledge understood best by those who lived it, which empowered them to make decisions affecting the quality of their lives. The new discourses abandoned the blandishments of excess found in the floating world of late Edo culture and sought ways to discipline this new force, to harness the body for productive work, master a history that they themselves now made through their own activity. This disciplining of the body resulted in reuniting mental and manual, head and hand, even thought and action, to eliminate the baneful effects of the division of labor that had shaped Tokugawa rule since its inauguration.

All of the new discourses, but most notably the Mito learning that propelled the sonno $\bar{j} \bar{i}$ activists, rejected the "totalization" of power that Tokugawa rule had installed in the eighteenth century even at the expense of its closest domainal supporters. Mito was the first to complain that this kind of totalization sacrificed the "branches" for the "trunk." It offered a progam for "realigning" designations and duties (meibunron) so that the role and duties of each rank in the vertical order would be accountable to its proper

'I'm following Derek Sayer's "multi-referential" and "non-exclusive interpretation" of Marxian general concepts, which articulates the superstructural dimension with the causal power of productive forces. See The Violence of Abstraction (London: Basil Blackwell, 1989), 36. 
"name" rather than only to shogunal authority. This meant that the shogunate itself should be mindful of its place and role in a hierarchy presided over by an emperor. Other discourses also rallied around Mito's recognition that too frequently the Tokugawa had failed to fulfill its ancient obligations, abandoning them more often than not for what Yokoi Shōnan identified as "private interest." Yet it was precisely by reidentifying the interest of the part that might stand in as an adequate substitute for the whole that the several discourses could articulate their own conception of social space.

Each of these discourses, it should be noted, supplied a conception of restoration. Mito had called early for a restoration or a revival (chük $\overrightarrow{0}$ ), and this goal was subsequently refined in the late Tokugawa period by loyalist activists like Yoshida Shōin, Maki Izumi, and Hirano Kuniomi. Nativism (kokugaku) appealed to an "adherence to foundations or the beginning" (moto ni tsuku) and ultimately contributed to framing the edict announcing the "restoration of archaic imperial authority" (ōsei fukko) in 1868; the several new religions epiphanized "world renewal" (yo naoshi) as a sacred sanctuary removed from the corrosions of contemporary history. Even the proponents of wealth and power envisioned a federation or conciliar arrangement that evoked China's archaic past (Three Dynasties) or Europe's early modern history, presided over by a despot who resembled Peter the Great more than a priest-king who had mastered ritual and magic. Armed with such notions of political restoration authorizing spheres of action, the several discourses tried to pull away from what had long symbolized the center and move toward the peripheral and the marginal. This surely explains the decision of activists to abandon Edo for Kyoto as the locus of planning and terror; they ultimately turned to the domains for protection and useful resources in the forthcoming struggle with the bakufu. Yet the move was transforming. Everyday life, which had always existed in the space that Marx described elsewhere as "living existence," on the margins of official culture and thought, moved to a terrain with many centers, not simply one. The several discourses envisaged a plurality of centers or simply peripheries achieved by secessions from the centrality of 
Tokugawa power. ${ }^{8}$ But the move to the periphery also created the "publicity" of political life and a new way of enfranchising the groups and classes that for too long had been kept outside the arena of political participation. More than most discourses, the Mito/ loyalist intervention used the public realm as a forum for discussing and even acting on issues that affected society as a whole. Between discussions of the importance of the public realms as part of the "living existence" and calls for immediate action to prevent disaster, it was often difficult to discern the anguished declarations of Yoshida Shōin that few, like himself, cared for the fate of the realm or the more measured anxieties of Sakuma Shozan that the "welfare" or "safety of the realm" was in jeopardy. The Mito/loyalists projected a public space for "discussion" ("public opinion" or "consultation," as it was called) indistinguishable from other forms of expression, work, prayer, writing, and action, not to mention other discourses. This new space signaled both the dissolution of an administrative politics in which the division between ruler and ruled had been presumed to be fixed for all time and the formation of a new situation characterized by unstable political practices, in which the very identity of the contesting forces was constantly shifting, slipping, and demanding redefinition. Moreover, as loyalist-activists never tired of affirming, the discursive field was marked by horizontality, by practices that presupposed an incomplete and open character. Challenging the claims of closure with openness, and determinacy with the perils of indeterminacy, the new discourses had to find a mode of mediation between the recognized need to stabilize society and promote production and local demands to preserve the various social identities that had appeared in the new space of restoration.

Only the presence of a vast area of semiautonomous, heterogeneous, and unevenly developed discourses and the danger of imminent conflict made it possible to organize a terrain for a hegemonic-practice that could satisfy the demands for order, productivity, and difference. It is possible to imagine this terrain,

${ }^{8}$ Ross, The Emergence of Social Space, 38, 45, for both this formulation and the quotation from Marx. 
occupied by differing groups projecting a conception of restoration that reflected a "living existence," almost as if competing to see which part would next stand in for the whole. Despite setbacks, loyalist-activists possessed clear material advantages on this terrain that enhanced their chances for leadership. Yet nothing in this discourse suggested the inevitability of the later establishment of the Meiji state and the elimination of competing social identities (regional and religious) under the regime of a centralizing political apparatus. For many, including loyalist-activists, the Restoration vaguely promised that they could retain the space of their own restoration in the realization of a hegemonic formation committed to stabilizing society and preserving the interests of production derived from the daily life.

The new discourses could easily support a restoration symbolized by an emperor (who hadn't actually ruled for more than a thousand years) and a court that promised nothing more binding than a return to the mythic Emperor Jimmu (even though he was not acknowledged as mythic in that time) as the model for an anxious present and an uncertain future. The important issue of which age or restoration to recall was debated among activists and wouldbe revolutionaries before 1868 . They rejected more recent precedents like the historically accessible Kemmu Restoration of the fourteenth century because it had failed, choosing instead the more remote (if not specious) "model" of archaic times. Moreover, the restorers/revolutionaries envisaged an elaborate political mapping that reproduced in every detail the administrative form of the eighth-century polity, with all of its titles and bureaus, in order to achieve the archaic purpose of a saisei itchi, the unification of ceremony and polity under the direct authority of the emperor, who was both religious ritualist and political ruler. In this way, the Restoration contained a promise to retain the space of restorations, momentarily finding a necessary fit between the forces that combined to bring down the Tokugawa and a hegemonic political structure that now proposed to reinstate order and security, augment production, and distribute relief and resources while preserving regional autonomies and local intensities. Uncertain as to its 
xxii

future goals, the ossei fukko dreamed by all (elegaically captured by Shimazaki Tōson's epic Yoakemae) could project an imaginary that might account for the interests of all social groups by presupposing a certain equilibrium among the various forces that had occupied the terrain of contest in the late Tokugawa period. So powerful and compelling was the appeal of this imaginary that the nativist scholar Suzuki Masayuki could enthusiastically announce in a chöka (a long, archaic poem composed on auspicious occasions) that "the emperor, hidden in the shade like a night flower, will flourish increasingly / Everyone will rejoice in the prospect of the new age."

The performance of recalling a distant time and seeking to resituate it in the present disclosed both the spatial play of restoration and the desire to master the historicity of the moment (Ross calls this conjuncture "spatial history"). It revealed a figure from outside time recruited to manage a momentous, epochal event in time. The Meiji Restoration resembles the first French Revolution, as observed by Marx in The 18th Brumaire of Louis Bonaparte: "And just when they seem to be revolutionizing themselves and things, in creating something that has never yet existed, precisely in such periods of revolutionary crisis they anxiously conjure up the spirits of the past to their service and borrow from them names, battle cries and costumes in order to present this new scene of world history in this time-honored disguise and this borrowed language." For a moment the Restoration constituted what Walter Benjamin once called a "dialectical image," bringing past into present, Then into Now-Time, historicizing and symbolizing retroactively a "non-historical place," the space of Restoration itself. Even though this imaginary was soon discarded by a centralized state formation unwilling to accommodate the plurality of interests and entertain the possibility of a hegemonic arrangement, the figure of Restoration drawn from outside time still carried the meaning of "will have been," as an event "that comes from the future." 10 Such a figure would continue to be summoned and even mobilized from

${ }^{9}$ Karl Marx, The 18th Brumaire of Louis Bonaparte (New York: International Publishers, 1969), 15.

${ }^{10}$ Slavoj Zizek, The Sublime Object of Ideology (London: Verso, 1989), 142. 
time to time in the twentieth century to recall for Japanese, at those critical moments identified by Althusser as "space without places, time without duration," that the modern state apparatus and its social order had exacted too high a price. ${ }^{11}$ Japanese would be reminded that the modern state, since the $1890 \mathrm{~s}$, had failed to deliver the original promise offered by the Restoration, which invariably required the implementation of a restoration of spaces as the only defense against an unmastered contemporary history and unmasterable modernity. Yet for others, this representation of space would appear as the place to reunite the improbable opposites of poetics and history, figure and its fullfillment, which late Tokugawa society momentarily achieved, like a "tiger's leap." 12

${ }^{11}$ The quote has been suggested by Homi K. Bhabha, ed., Nation and Narration (London: Routledge, 1990), 294. The original appears in Louis Althusser, Montesquieu, Rousseau, Marx (London: Verso, 1972), 78.

${ }^{12}$ Walter Benjamin, Illuminations, edited and with an introduction by Hannah Arende, trans. by Harry Zohn (New York: Schocken, 1976), 261. 
